\title{
Impact of a Pulsed Magnetic Field on a Hard Alloy During Machining on Heavy Machine Tools
}

\author{
Viktor Kovalov \\ Donbas State Engineering Academy (DSEA), Akademichna 72, 84313, Kramatorsk, Ukraine \\ Yana Vasilchenko \\ Donbas State Engineering Academy (DSEA), Akademichna 72, 84313, Kramatorsk, Ukraine \\ Maksym Shapovalov \\ Donbas State Engineering Academy (DSEA), Akademichna 72, 84313, Kramatorsk, Ukraine
}

Raul Turmanidze

Georgian Technical University (GTU), 0175 Tbilisi, Georgia

Predrag Dašić

Faculty of Strategic and Operational Management (FSOM), 11000 Belgrade, Serbia

SaTCIP Publisher Ltd., 36210 Vrnjačka Banja, Serbia

Received (30.03.2018.); Revised (12.09.2018.); Accepted (14.11.2018.)

\begin{abstract}
Analysis of the tool work and refusals when heavy machines cutting shows the necessity to use methods of bulk modification for improving structural strength and fracture resistance of cemented carbide cutting plates. It is suggested to test cutting plates to assess the structural strength limit. The accelerated method to estimate the resistance to scattered contact damage and chipping resistance is developed. It is obtained that the pulsed magnetic field treatment (PMNF) of cutting plates (85\% WoC, 5\% TiC, 10\% Co) leads to a dependent on treatment regime increase in structural bending strength limit under static load. The PMTF allows increasing the resistance to scattered contact damage and chipping resistance for cutting plates (92\% WoC, $8 \%$ Co). It is shown that physical method of pulsed magnetic field treatment is promising for modification of tool materials.
\end{abstract}

Key words: Heavy machine, Cemented carbide, Structural strength, Resistance to scattered contact damage, Chipping resistance, Pulsed magnetic field.

\section{INTRODUCTION}

The efficiency of the metalworking process of parts is largely determined by the resource of the cutting tool. System "tool-detail" is one of those which is defined as extreme loaded - terms of its operation are high temperature and ultra-high static and cyclic contact loadings. "Extremity" of such system increases when processing on heavy machine tools. Its significant features include the large size of the processed parts (cylinders, shafts, rods, bands up to $24,000 \mathrm{~mm}$ and larger in length, up to $5000 \mathrm{~mm}$ in diameter, up to 250 tonnes in weight) and large depth of cut (15 ...20 mm) and feed (to $3 \mathrm{~mm}$ ), the high cost of blanks, a great path of cutting, high production costs associated with the cost of the unique equipment, unevenness of allowances [1-5].

\section{THE CARRIED OUT RESEARCHES}

Tool failure analysis of processing on heavy machine tools shows that along with the failure of the tool due to wear, up to $80 \%$ of failures can be caused by brittle fracture of the carbide cutting point, which makes itself felt in the flaking of the cutting edges and chipping of the cutting point.

This is due to the fact that high values of the slice thickness cause increase of the intensity and the active zone of tensile stress on the front face of the tool while structural bending strength significantly differs from those obtained on standard samples and depends on the granularity and porosity of carbides, cobalt content, surface condition of the cutting plate. Tool failure analysis also found heterogeneity of the degree of different parts of cutters and mills removable plates degradation, typical for heavy machinery [6].

Directions in solving the tool life extention problem for heavy engineering are to provide surface and volume strength. Ways to obtain tool materials with range of necessary characteristics in terms of processing on heavy machine tools are surface modification technologies that allow you to control the strength and defectiveness of tool materials surface layers and technologies of materials and tools volume modification. 

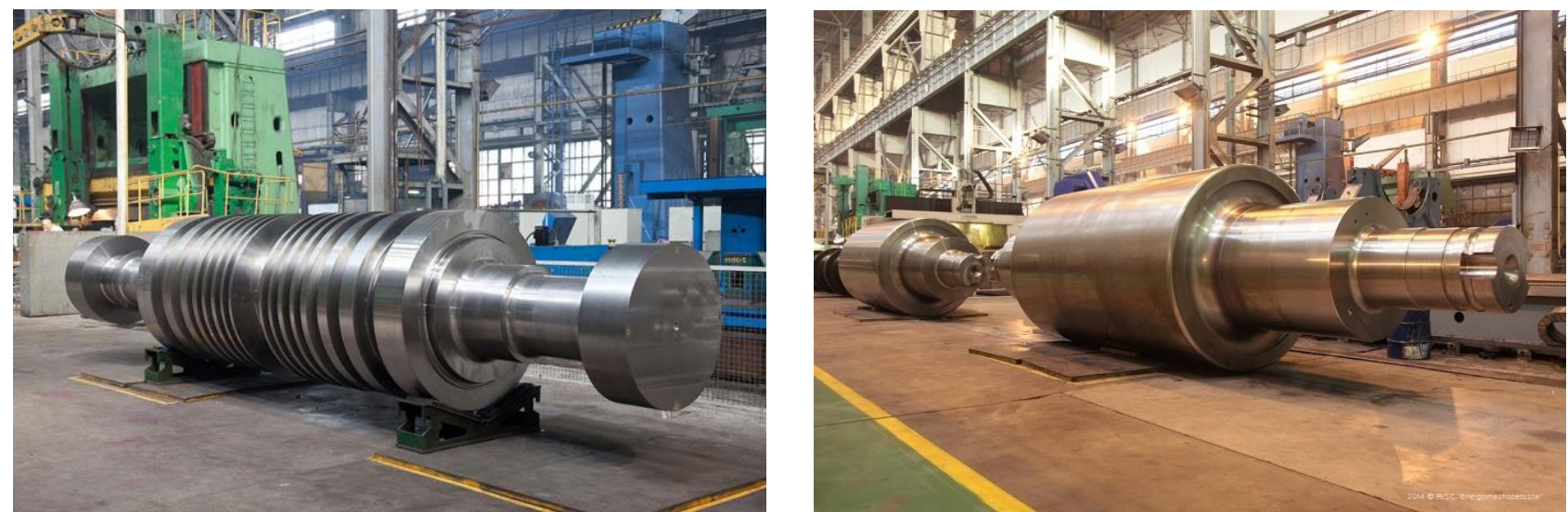

Figure 1. Parts-representatives of products of heavy engineering enterprises

According to the results of detailed analysis of the operating conditions and problems associated with the failure of tool a system approach of ensuring tools strength and efficiency based on methods of tool materials volume and surface modification and on structural strength and defectiveness indicators control was developed and implemented.

Directions in solving the tool life extention problem for heavy engineering are to provide surface and volume strength. Ways to obtain tool materials with range of necessary characteristics in terms of processing on heavy machine tools are surface modification technologies that allow you to control the strength and defectiveness of tool materials surface layers and technologies of materials and tools volume modification. According to the results of detailed analysis of the operating conditions and problems associated with the failure of tool a system approach of ensuring tools strength and efficiency based on methods of tool materials volume and surface modification and on structural strength and defectiveness indicators control was developed and implemented.

According to results of inspection of carbide edge tools from different manufacturers which were withdrawn from service, types of limit wear and fracture, and speciality of material damage in different parts of working surfaces of the blade were defined. It was shown that the main types of surfaces fracture in the local load are microplastic deformation, brittle fracture of face and back working surfaces on modes of rupture and shear and macrofracture of plates in bending.

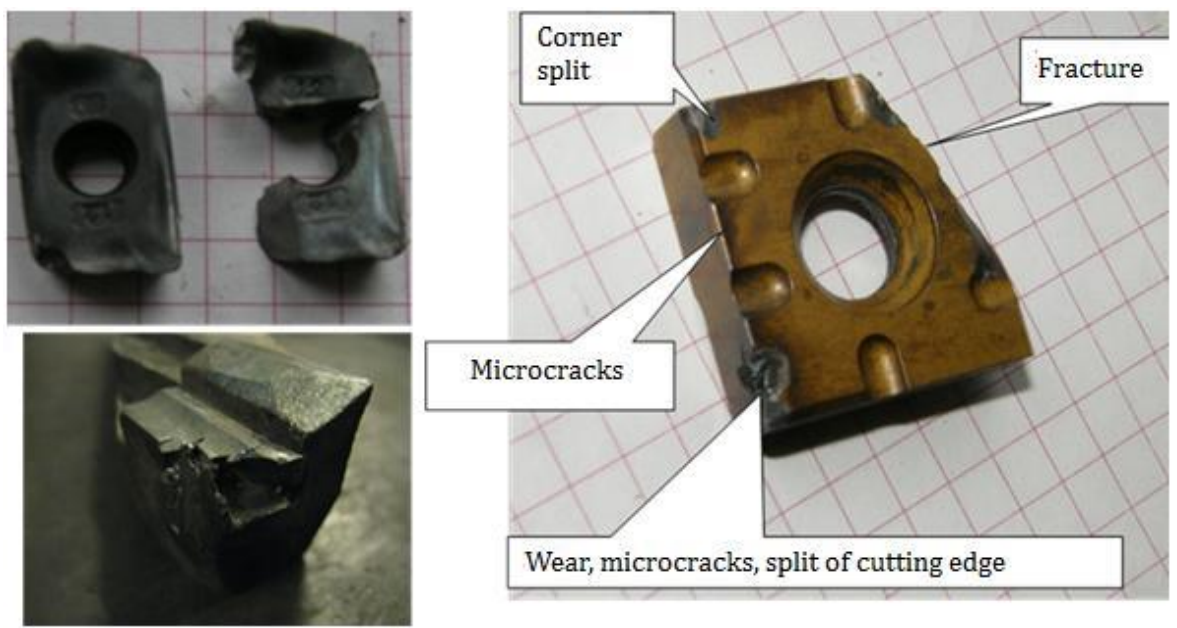

Figure 2. Destruction of cutting plates in processing on heavy machine tools

The methodical principles of laboratory and industrial tests of strength, resistance to brittle fracture and damage to materials and carbide tools were developed. An examination of sources of plates fracture was carried out and it was shown that structural strength of the cutting plates is significantly different from the results of assessing the strength obtained by testing standard specimens made of solid carbide.
Control of defectiveness of carbide plates was done and a method of determining the actual level of indicators of volume and local strength was developed. Integral complex of methods and experimental tools for obtaining the characteristics of strength and fracture under conditions approaching the operational was refined. Some tools and techniques can be applied to the incoming production quality control of tools and the level of its damage at various stages of operation. 


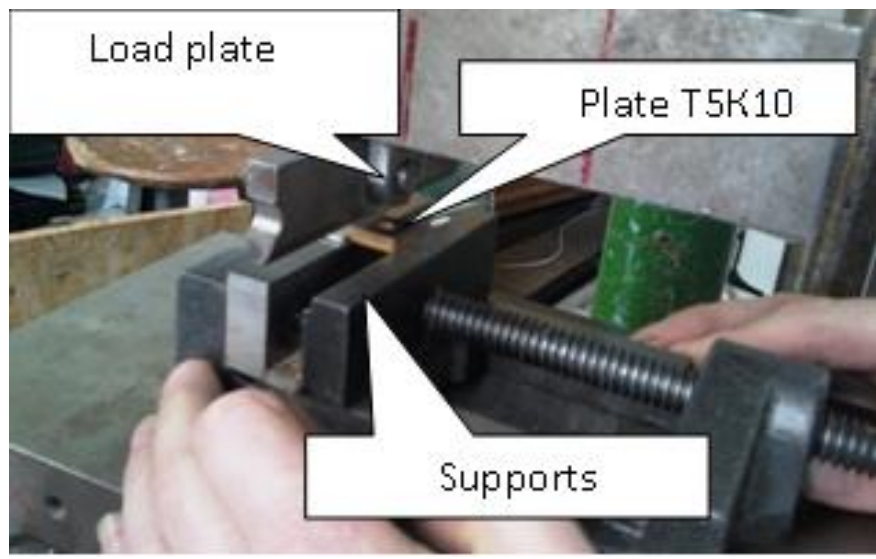

Figure 3. Testing for bending of removable cutting plate with T5K10 on the equipment ZD-4

In terms of structural strength of brittle materials comprehensive experimental evaluation of strength fracture resistance and efficiency of carbide plates was performed, which is essential for the development of advanced technologies of tools strengthening and their optimization by parameters of durability and efficiency.

There were created the synthesis foundations of "basestructured PVD coatings" system with predictable and controlled stress-strain state, allowing to ensure the strength of coverage at the stage of planning, production and operation under considerable tensile stress inherent to operating conditions for heavy machine tools.

\section{PHYSICAL BASIS OF METHOD}

The experience of theoretical and practical study of the cutting process allows to define it as nonstationary, characterized by a set of parameters that strongly depend on the initial conditions of implementation in time. In many cases this is due to the structural state of the processed material, the cutting tool material, their temporal transformation. World practice of obtaining and use of construction materials shows that their properties are determined in many cases by the structural features, but this area is not researched enough. The results of research in the field of machining shows that machining is due to the structure of the materials that come into contact in the treatment zone. The structure of the processed material and of the cutting tool material involves laws of mechanics, thermal physics, physics and chemistry of the process of contact interaction in the area of cutting, parameters of durability, wear and tool life, products surface layer deterioration state, the efficiency of treatment. Considering the variety of processed materials and materials for cutting tools, knowledge of parameters describing their structure gains priority.

One of the most promising technologies to improve the performance properties of products applied in various fields of technology is pulsed magnetic field treatment. With magnetic influence substance changes its physical and mechanical properties. The interaction of pulsed magnetic field with detail of conductive material is the more intense, the higher the structural and energetic heterogeneity of material are. Therefore, the higher

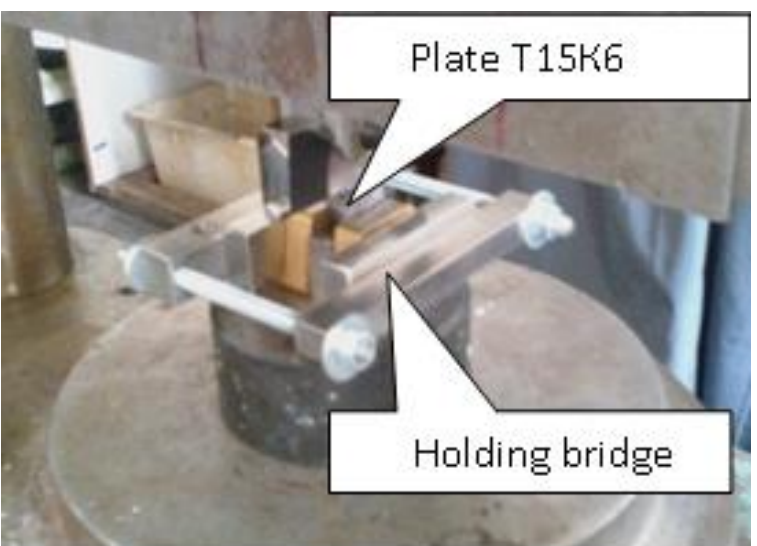

Figure 4. Testing for bending of removable cutting plate with T15K6 on the equipment ZD-40

concentration of surface and internal stresses in the metal workpieces is, the more likely the local concentration in them of microforelocks of the external field and the longer the flow of relaxation processes in the material are. When making the real parts a certain amount of excess energy is unevenly concentrated in the material and with an increase of it increases the probability of destruction of part.

Using magnetic pulse treatment can significantly reduce the excess energy of the material associated with concentration of internal and surface stresses in the concrete part, and reduce to a minimum the probability of failure.The installation of PMFT consists of a pulse generator with power supply and inductor. Pulse generator and power supply are designed as separate electrical racks. External inductor is connected to the generator via a cable. The installation of PMFT is compact, environmentally friendly, does not require much energy and maintenance, works without highly skilled service. The equipment consists of the block of a pulse shaping, microprocessor control unit, display and operating modes, solenoid block in which processing occurs. For small products inductor is placed on a horizontal insulating diamagnetic surface (plastic, wood, rubber, etc.), the axis of inductor must be vertical. Products are placed within the inductor and the treatment session is carried out, and lasts $30 \ldots 120$ seconds.

Reasons for changes in the properties of tool materials under PMFT are reduced to the restructuring of atoms under the influence of a magnetic field. Interaction of a pulsed magnetic field with a conductive tool material occurs more intensively than higher energy and structural heterogeneity of the material. When manufacturing the tool some amount of excess energy unevenly concentrates in its material, with the increase of which increases the probability of failure of the tool.

When exposed to the material of pulsed magnetic field directional orientation of the free electrons of matter takes place, thereby changing the structure and phase relationship, creating tensions in the crystal lattice, causing the motion of defects and dislocations.

Another extremely interesting result is the change in the chemical composition of the surface layer of material to a depth of $500 \mathrm{~A}_{0}$ - as a result of PMFT content of elements such as tungsten, vanadium and molybdenum is increased. 

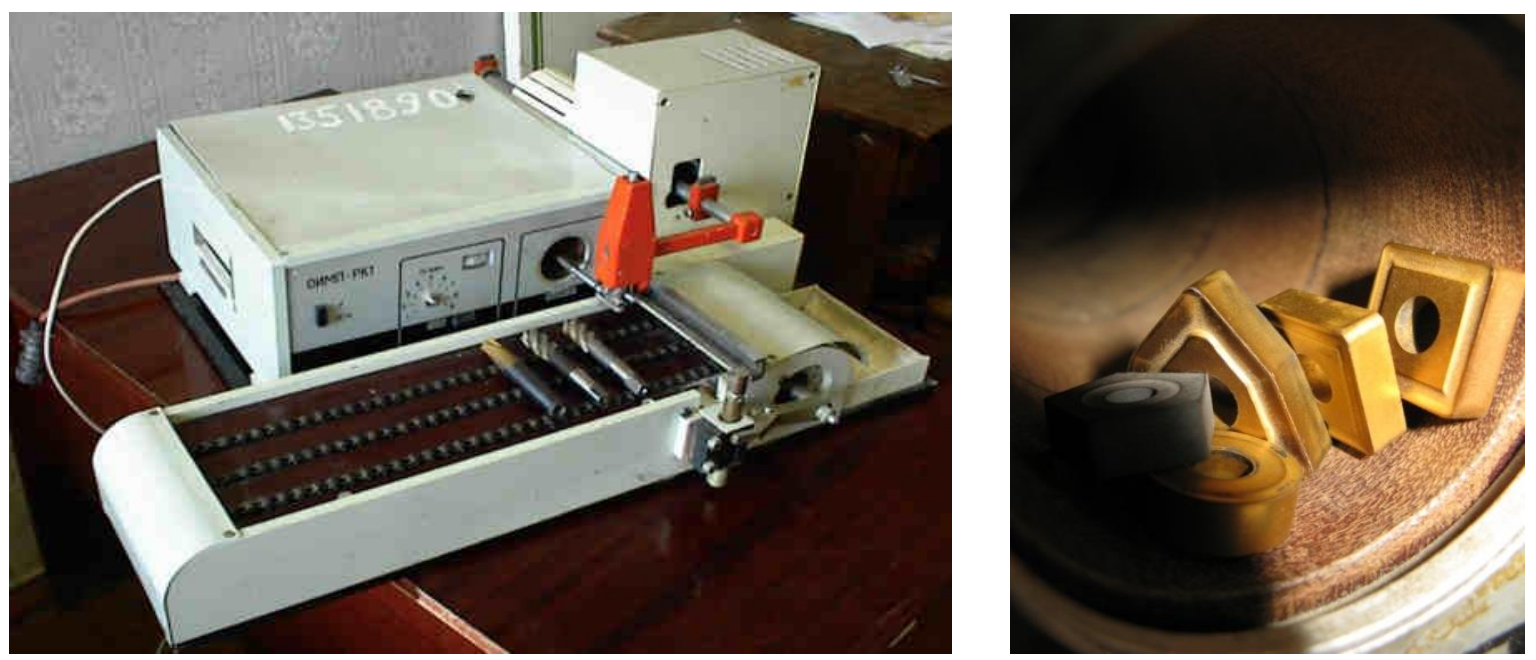

Figure 5. Equipment for magnetic-pulse treatment

PMFT process control parameters are the time of magnetization and demagnetization, the magnetic field strength, the pulse repetition frequency and their duration.

Processing modes are set depending on the cross sectional area of the workpiece.

PMFT application can significantly reduce the excess energy of the material associated with the concentration of internal and surface stresses, and reduce the likelihood of its destruction. The effect of the application of PMFT is more significant, the lower the quality of the cutting tool is. Therefore, this method is also used to improve the reliability of the tool [7-9].

The resulting effect of improving the quality from the magnetic-pulse treatment is due to metastable state of the system and its components resonant response to dynamic electromagnetic influence.

For a comprehensive study of PMFT it is also important to study the mechanism of change of operational properties of tools after processing associated with aftereffect.

PMFT puts the system into a state of lower free energy through the state with higher free energy. Changing the matter energy density at entering it into a uniform magnetic field (what can be considered a field in a solenoid with certain assumptions):

$$
d W=T d S-I d H-p d V
$$

The free energy changes under this:

$$
d G=-S d T-I d H+V d p
$$

When machining of hard carbides the effect of PMFT on structure and properties of the components was studied. It is known that the strength of carbides is largely determined by the binder phase. Observations of the expansion of destructive cracks showed that in VK and TTK carbides breaking crack extends mainly by cobalt phase, and in TK carbides where destructive crack extends mainly in phase $(\mathrm{Ti}, \mathrm{W}) \mathrm{C}$, the cobalt component can inhibit destructive crack. Cobalt carbide phase is a solid solution of $\mathrm{W}$ and $\mathrm{C}$ in the cubic Co. Ordered arrangement of atoms differs with lower internal energy compared with a disordered, especially if the distribution of atoms on specific sites of the crystal lattice occurs at a relatively low temperature, when the entropy associated with the disorder, plays a less significant role.

Changing the properties of cobalt phase after PMFT reduces to the restructuring atoms under the influence of the magnetic field. Energy required for separation or recrystallization of the dispersed phase, is higher than the energy of the magnetic field, creating an effect of PMFT. Consequently, PMFT cannot influence the phase composition and texture of the material. However, the selection of phase, crystallization or stress may develop along such crystallographic directions that the energy of crystallization or separation will be minimal in a certain direction depending on the direction of the magnetic field.

In any inhomogeneous material concentration will change approximately periodically with respect to some mean value (one-dimensional case):

$$
C(x)=C_{0}+C_{m} \cos (\pi x / l)
$$

This corresponds to a change in the concentration at a distance $I$ along the $x$ axis from the maximum value $C_{0}+C_{m}$ to a minimum $\mathrm{C}_{0}-\mathrm{C}_{\mathrm{m}}$. These gradients will decrease gradually due to the movement of the dissolved element from the regions having a high concentration in a lower concentration. If the diffusion coefficient does not depend on the composition,

$$
C(x, t)=C_{0}+C_{m} \cos (\pi x / l) \exp \left(-\pi^{2} D t / l^{2}\right) \text {. }
$$

This means that the transition from the $\mathrm{C}$ concentration to the final concentration $\mathrm{CO}$ at any point in the sample is

$$
C-C_{0} \approx \exp (-t / \tau)
$$

where $\tau$ - relaxation time.

Decrease in $\mathrm{T}$ is contributed by increase of the diffusion coefficient $D$ and reducing the distance I concentration maxima and minima.

For cubic lattices the diffusion coefficient:

$$
D=1 / 6 \Gamma \alpha^{2},
$$

where $\Gamma$ - frequency of atoms hopping 
$\alpha$ - the grating period.

Hopping frequency:

$$
\Gamma=z v \exp (-\Delta G / R T),
$$

where $z$ - number of neighboring atoms,

$v$ - share of fluctuations in this direction that will lead to hopping of atoms;

$\Delta G$ - the change in free energy of the lattice. Improving the strength of carbide tools, processed with pulsed magnetic field, confirmed by laboratory tests of cutters by the "breaking feed" method, could also be explained, probably, with a decrease in tensile stresses in the cobalt phase, which prevents the spread of destructive cracks in the cobalt carbide phase, i.e. leads to an increase in its strength.

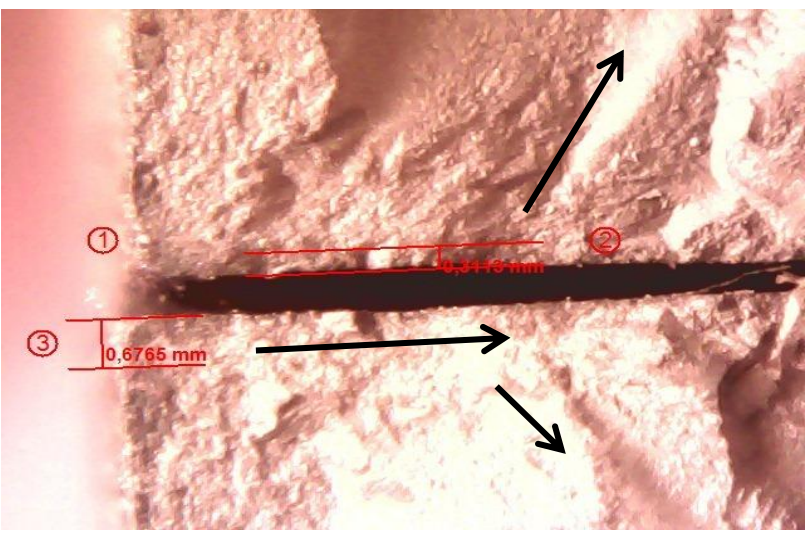

a) Sample without treatment $\sigma_{\text {bend }} 1477 \mathrm{MPa}$

\section{THE ACHIEVED EFFICIENCY}

It was found that modification of carbides T5K10, T15K6, VK3 and VK8 with pulsed magnetic field leads to increasing of homogeneity of carbides, reducing the thickness of the fractured layer, depending on the applied modes - to the growth of bending strength border under static load of up to $27 \%$, which allows to predict growth of endurance limit. Laboratory tests of cutters equipped with carbide plates by "destructive feeding" method show an increase in period of resistance to fracture by $17 \%$ and reduction by $34 \%$ in coefficient of variation.

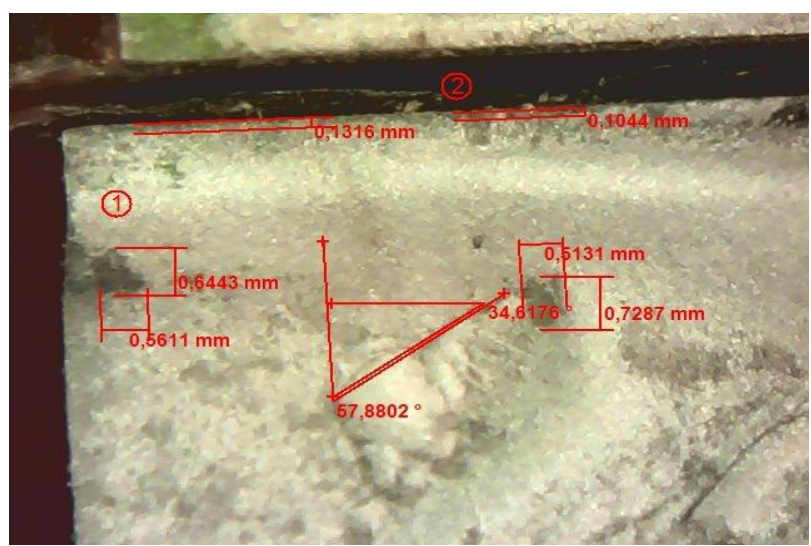

b) Sample after PMFT $\sigma_{\text {bend }}-1653 \mathrm{MPa}$ increased uniformity, less relief of fracture

Figure 6. The focus of fracture and primary area of main crack growth of specimen made of brazed plate with VK8

It was found that the magnetic-abrasive treatment increases the value of the rounding radius of cutting edges, increases hardness to a depth of 150-170 microns, bending strength limit up to $20 \%$ and provides increase of stability EUMP by 2.5 times.

The complex of scientific and technical and pilot scale works to assess the indicators of efficiency of modified
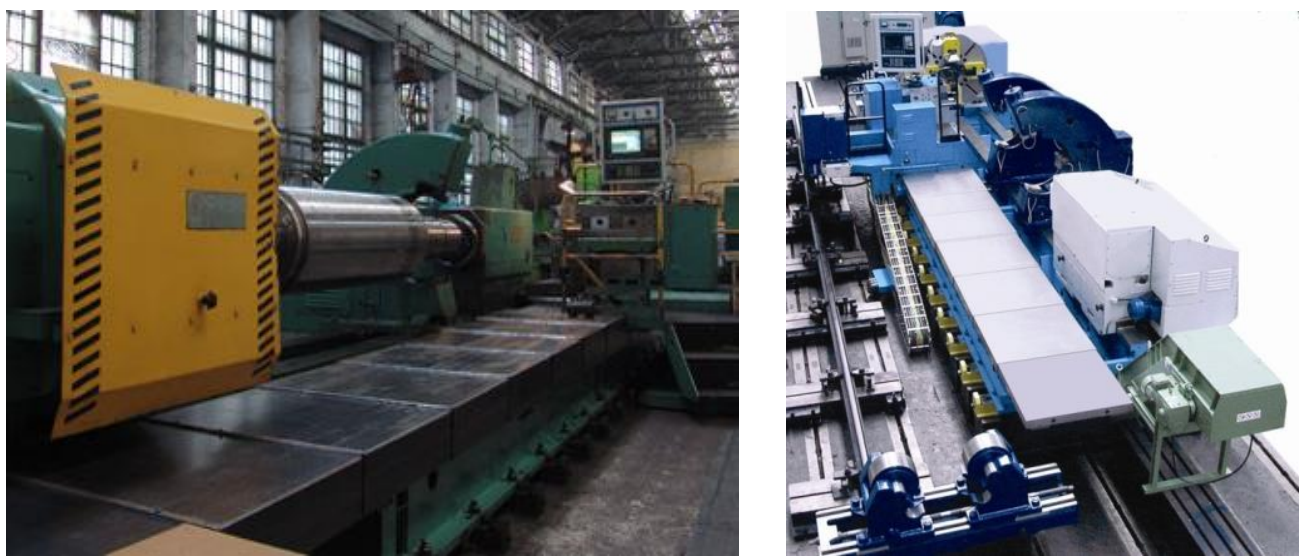

Figure 7. Heavy lathe in the machine shop NKMZ

\section{CONCLUSION}

Production tests of cutters equipped with removable multifaceted indexable cutting plates with structured coatings parameters which are optimized in terms of carbide plates was carried out [10]. Performance tests were conducted on heavy lathes in machine shops number 3 and number 5 of CJSC NKMZ, on machine tools of models KJ.16274f3, 1A670f3 and in laboratory conditions on the machine tool of $1 \mathrm{~A} 64$ model. strength, showed that tool life increased by 1.6 times compared to an instrument with complete coating.

Analysis of the results of modular carbide cutters with plates T5K10 hardened with PMFT comparative 
performance testing showed strengthening of reliability indices: the coefficient of variation stability decreased by 2.33 times, the average period of stability increased by 1,6 times, gamma-interest period of stability for $\mathrm{Y}=$ $80 \%$ increased by 3,5 times, which is especially important for heavy CNC lathes

\section{REFERENCES}

[1] Kovalev, V.D., Vasilchenko, Y.V. and Dašić, P. (2014), "Adaptive optimal control of a heavy lathe operation". Journal of Mechanics Engineering and Automation (JMEA), Vol. 4, No. 4, pp. 269-275.

[2] Kovalev, V. and Vasilchenko, Y. (2011), "Statistical researches of work of the enterprises of heavy mechanical engineering for a substation of technical characteristics of new machine tools" in Dašić P. (Ed.), Research and Development in Mechanical Industry (RaDMI-2011) proceedings of the 11th International Conference in Sokobanja, Serbia, SaTCIP Publisher Ltd., Vrnjačka Banja, pp. 359-364.

[3] Kovalov, V., Vasilchenko, Y. and Dašić, P. (2015), "Development of the integral complex of optimal control of heavy machine tools adaptive technological system for wind-power engineering parts". Procedia Technology, Vol. 19, pp. 145-152. doi: 10.1016/j.protcy.2015.02.022.

[4] Kovalov, V., Antonenko, Y. and Dašić, P. (2016) "Method of structural design of heavy machine tools". Procedia Technology, Vol. 22 pp. 146-152. doi: 10.1016/j.protcy.2016.01.023.

[5] Khoroshailo, V., Kovalov, V. and Dašić, P. (2016) "Improving of vibration resistance of boring tools by big diameter holes tooling on lathe". Procedia Technology, Vol. 22, pp. 153-160. ISSN 2212-0173. doi: 10.1016/j.protcy.2016.01.038.

[6] Kovalev, V. and Vasilchenko, Y. (2012), "Optimization of cutting parameters considering the actual process state in real time environment in heavy engineering" in Dašić P. (Ed.), Research and Development in Mechanical Industry (RaDMI-2012) proceedings of the 12th International Conference in Vrnjačka Banja, Serbia, SaTCIP Publisher Ltd., Vrnjačka Banja, pp.

[7] Kovalev, V.D., Zinoviev, N.I. and Klimenko, G.P. (1999), "Increase of operational characteristics of the cutting tool by PMFT method". Optimal Control of Mechatronic Machine Tool Systems, Vol. 1999, pp. 43-46.

[8] Kovalev, V.D., Klimenko, G.P. and Vasilchenko, Y.V. (2004), "Application of pulsed magnetic field treatment for hardening of machine parts and cutting tools". Scientific and Technical Journal Newsletter of Engine-Building, №. 4, pp. 149-151.

[9] Kovalev, V.D., Miroshnichenko, Y.V., Vasilchenko, Y.V. (2005), "A method of combined hardening of cutting tools and machine parts" in Heavy Machinery. Challenges and Prospects for Development Abstracts of the 30th International Scientific and Technical Conference in Kramatorsk, Ukraine, Donbas State Engineering Academy (DSEA), Kramatorsk, pp. 51-52.

[10] Rodichev, Y., Soroka, H., Kovalov, V., Vasilchenko, Y. and Savelova, I. (2013), "Predicting the fatigue strength of hard alloys, treated with pulsed magnetic field" in Dašić P. (Ed.), Research and Development in Mechanical Industry (RaDMI2013) proceedings of the 13th International Conference in Kopaonik, Serbia, SaTCIP Publisher Ltd., Vrnjačka Banja, pp. 254-259.

\title{
Uticaj impulsnog magnetnog polja na tvrdu leguru tokom obrade na alatima teških mašina
}

\author{
Viktor Kovalov, Yana Vasilchenko, Maksym Shapovalov, Raul Turmanidze, Predrag Dašić
}

Primljen (30.03.2018.); Recenziran (12.09.2018.); Prihvaćen (14.11.2018.)

\begin{abstract}
Analiza rada alata i odbacivanja pri sečenju težim mašinama pokazuje neophodnost upotrebe metoda modifikacije mase za poboljšanje strukturne čvrstoće i otpornosti na lomljenje cementnih karbidnih reznih ploča. Predlaže se testiranje reznih ploča radi procene ograničenja strukturne snage. Razvijena je ubrzana metoda za procenu otpornosti na rasuto kontaktno oštećenje i otpornost na cepanje. Dobijeno je da tretman impulsnim magnetnim poljem (PMNF) reznih ploča ( $85 \%$ VoC, $5 \%$ TiC, $10 \%$ Co) dovodi do zavisnosti od povećanja režima tretmana u graničnoj strukturi savijanja pri statičkom opterećenju. PMTF omogućava povećanje otpornosti na rasuto konktaktno oštećenje i otpornost na cepanje za rezne ploče (92\% VoC, $8 \%$ Co). Pokazano je da je fizički metod tretmana pulsnim magnetnim poljem obećavajući za modifikaciju materijala alata.
\end{abstract}

Ključne reči: Teška mašina, Cementni karbid, Strukturna čvrstoća, Otpornost na rasuto kontaktno oštećenje, Otpornost na cepanje, Impulsno magnetsko polje. 